University of Michigan Law School

University of Michigan Law School Scholarship Repository

\title{
Double Tax Treaties: An Introduction
}

\author{
Reuven S. Avi-Yonah \\ University of Michigan Law School
}

Available at: https://repository.law.umich.edu/book_chapters/131

Follow this and additional works at: https://repository.law.umich.edu/book_chapters

Part of the International Law Commons, and the Taxation-Transnational Commons

\section{Publication Information \& Recommended Citation}

Avi-Yonah, Reuven S. "Double Tax Treaties: An Introduction." In The Effect of Treaties on Foreign Direct Investment: Bilateral Investment Treaties, Double Taxation Treaties and Investment Flows, edited by K. P. Sauvant and L. E. Sachs, 99-106. Oxford: Oxford Univ. Press, 2009.

This Book Chapter is brought to you for free and open access by the Faculty Scholarship at University of Michigan Law School Scholarship Repository. It has been accepted for inclusion in Book Chapters by an authorized administrator of University of Michigan Law School Scholarship Repository. For more information, please contact mlaw.repository@umich.edu. 


\title{
4. DOUBLE TAX TREATIES: AN INTRODUCTION
}

\author{
REUVEN S. AVI-YONAH
}

The existing network of more than 2,500 bilateral double tax treaties (DTTs) represents an important part of international law. The current DTTs are all based on two models, the Organisation for Economic Co-operation and Development (OECD) and United Nations (UN) model DTTs, which in turn are based on models developed by the League of Nations between I927 and I946. Despite some differences that will be discussed below, all DTTs are remarkably similar in the topics covered (even the order of articles are always the same) and in their language. About $75 \%$ of the actual words of any given DTT are identical with the words of any other DTT. Thus, the DTT network is the most important element of the international tax regime, that is, the generally applicable rules governing income taxation of cross-border transactions. Indeed, I have argued that given the similarities among all DTTs, certain rules embodied in them (such as the requirement to prevent double taxation by granting an exemption or a foreign tax credit) have become part of customary international law, and therefore may be binding even in the absence of a DTT.

DTTs are generally titled "Convention Between [Country X] and [Country Y] for the Avoidance of Double Taxation and the Prevention of Fiscal Evasion With Respect to Taxes on Income." This title provides us with quite a bit of information. First, DTTs are bilateral: They represent a bargain between two countries, like BITs but unlike other economic law treaties, such as the General Agreement on Tariffs and Trade (GATT). Moreover, unlike the BITs, DTTs generally do not contain a Most Favored Nation (MFN) article, which means that their provisions cannot be transferred to third countries.

Second, the title states that the DTT, like all DTTs, is for the "Avoidance of Double Taxation and the Prevention of Fiscal Evasion." In truth, DTTs are generally not necessary to prevent double taxation, although they may help in borderline situations, such as cases where the source of income is disputed. This is because almost all countries prevent double taxation (i.e., taxation by both the residence and source country) unilaterally by having the residence country either grant an exemption to foreign source income or grant a foreign tax credit for source country tax on that income. Since these provisions apply unilaterally without a DTT, DTTs are generally not needed to prevent double taxation.

If DTTs do not address double taxation, what do they do? DTTs shift tax revenue from source countries to residence countries, because under the generally 
accepted rules, the source country is allowed to impose the first tax on any revenue deriving from sources within it. In the absence of a DTT, source countries can tax both active and passive income within the country. In addition, source countries are not bound by a permanent establishment or DTT sourcing rule defining what income originates within the country.

DTTs shift the burden of taxation from source to residence country in two ways. The main mechanism for active income is the definition of permanent establishment. DTTs generally bar source-based taxation unless an enterprise of the other state has a permanent establishment, i.e., some kind of fixed base of operations directly or through a dependent agent, in the source country. The main mechanism for passive income is a reduction in withholding at its source. The U.S. model DTT, for example, reduces taxation on interest and royalties to zero; the only category of passive income that is eligible for source-based taxation is dividends, which are taxed at a reduced rate. The OECD model DTT, which is the main model for developed countries, reduces tax on royalties to zero but has a positive rate on interest and dividends. The UN model DTT, which is the main model for developing countries, has higher rates of source-based taxation on passive income (and a lower permanent establishment threshold for active income), but even it shifts tax revenues from the source to the residence country.

This DTT structure works well if the flows of income are reciprocal, but it creates a problem for developing countries. In the reciprocal situation, residents of country A derive income from sources from country B, and residents of country B derive income from sources of income from country A. In the absence of the DTT, country A will tax the country B residents' source income, and country B will tax the country A residents' source income; both countries A and B will probably grant a tax credit or exemption to alleviate double taxation and encourage cross-border investment. The DTT shifts the taxation of some categories of income, particularly passive income, from the source to the residence country. Under the DTT, country B will not tax passive income that goes to country A residents, and country A will not tax passive income that goes to country B residents. As long as the capital flows are more or less reciprocal, the DTT reduces the administrative burden of imposing withholding taxes, and the net revenue is more or less the same. The amount that country A loses by not imposing its withholding tax is regained by not having to give credit for the taxes imposed by country B on income its own residents earn overseas. For example, suppose that investors from B are taxed on $\$$ IOO at a rate of $30 \%$ and this falls to $\% \%$, then A loses \$30 in revenue. This however would be offset if $\mathrm{A}$ also saw the tax on its \$IOo in investment on B fall from 30\% to ०\%, allowing it to tax this income at its standard rate. However, if A has no investment in B, then this is just a loss of $\$ 30$.

If the investment flow only goes one way, and investment always flows from country B into country A, then it is much harder to get into a DTT because a DTT will always transfer revenue from country A to country B. Thus, developing 
countries have traditionally not chosen to enter into DTTs with developed countries because the DTTs lead to a loss of tax revenue. Some developed countries, such as Germany, Sweden and Japan, have historically had extensive DTT networks with developing countries because they were willing to provide tax-sparing credits (credits for taxes that would have been collected at source but for a tax holiday), but the United States, which refuses to grant tax sparing in its DTTs, had few DTTs with developing countries until the i99os, although the situation has changed somewhat in recent years. One reason for the recent expansion in U.S. DTTs with developing countries is that the DTT provides certainty for U.S. investors regarding the tax law of the other country, and most developing countries consider it to their benefit to encourage U.S. investment. Another reason is that DTTs generally include an exchange-of-information provision that allows the developing country to obtain information exchanged from the United States, and developing countries have increasingly been interested in trying to tax capital invested by their rich residents overseas.

Since the OECD model is the source of most DTTs, we shall focus on it and compare it to the UN and U.S. models. One such difference is that the U.S. model DTT, but not the OECD or UN models, "shall not restrict in any manner any benefits now or hereafter accorded by the laws of either contracting state." In other words, from a U.S. perspective, DTTs may never increase taxation, but they may only reduce the taxation that would otherwise apply. One reason for this is that tax laws are passed by Congress as a whole, whereas DTTs are ratified only by the Senate. A tax increase through a DTT would be unconstitutional because it would never have been ratified by the House of Representatives. A related point is that the United States only allows DTTs to reduce foreign taxation of U.S. citizens and U.S. taxation of foreigners; DTTs cannot affect the way the United States taxes U.S. residents. This provision is written into the savings clause, appearing in most U.S. tax DTTs at the end of the first article. The savings clause also states that people who have lost their citizenship for tax -motivated reasons should be treated as if there were no DTT because the United States argues that DTTs are not designed to protect U.S. citizens from U.S. taxes.

Article 2 of the DTT states that the taxes covered in the DTT are only income taxes. For example, in U.S. DTTs, the Social Security tax, which is a payroll tax, is generally excluded and sometimes is covered by other agreements. Estate and gift taxes are also covered by other agreements. Thus, the DTT has the largest effect on the imposition of the income tax. Importantly, U.S. DTTs do not generally protect against any type of state tax (although in the OECD and UN models, sub-federal income taxes are covered). Most states have corporate and individual income taxes, which may impose a high burden. For example, a foreign company might wish to open an office in New York City to engage in preparatory and auxiliary activities, which are exempt from federal taxation by the permanent establishment article; however, the combined New York state and New York City 
corporate income tax can be as high as $20 \%$, imposing a significant tax burden on the company.

Article 4 covers residence and is important because it defines who is covered by the DTT. In general, groups covered by the DTT are tax residents (i.e., people considered residents for tax purposes, which generally requires physical presence greater than I83 days); tie-breaking rules are included to prevent dual-residency situations. Corporations are deemed to be residents in the country in which they are incorporated (the U.S. position) or in the country in which they are managed and controlled (the UK position).

Next we turn to a discussion of the substantive provisions. Article 5 covers permanent establishment. This provision is quite narrow in scope; in the OECD and U.S. models, the permanent establishment threshold is set high because they are for developed countries interested in reducing source-based taxation of capital-exporting enterprises. Thus, in the OECD and U.S. models, a construction facility or an oil drilling facility must be in the country for more than twelve months to be taxed, but in the UN model, it is only six months. The OECD and U.S. article also includes a long list of exceptions and a specific bar against force-of-attraction rules (such as found in the UN model) in which income is taxed when there is a permanent establishment, even though it is not attributable to the permanent establishment.

Article 6 covers real property; taxation of real property at source is allowed, including, as under the U.S. rule, corporations most of whose assets are real property. Article 7 is the business profit article, which talks about taxation of business profits only if they are connected to a permanent establishment; Article 9 is the associated enterprise article, which says that if there is a transfer pricing adjustment and the other country agrees to it, then the other country shall make a corresponding adjustment to prevent double taxation - but notice that the other country must agree. Many transfer pricing adjustments, unfortunately are not agreed to by the other country and result in double taxation (source-source double taxation), so this article is only of a little help.

The subsequent articles reduce source-based taxation on passive income, dividends, interest, royalties, and capital gains. These articles are the heart of the DTT, whose main function (as explained above) is to reduce source-based taxation of passive income. Under the U.S. model, the only source-based taxation that is allowed is the tax on dividends; there is no tax at all on interest, royalties, or capital gains. The OECD model, by contrast, permits tax on interest. Under the U.S. model DTT, a tax of $5 \%$ is allowed on direct dividends (dividends to corporations that own a high percentage of the shares) and $15 \%$ for portfolio dividends, but recent U.S. DTTs reduce the tax on direct dividends to zero.

The next articles address independent services and other special topics. Article 22 of the U.S. model covers limitation of benefits and is a major element in modern U.S. DTTs. The limitation-of-benefits article is designed to prevent treaty-shopping (i.e., the use of treaties between two countries by parties from a third, nontreaty country to obtain withholding tax reductions) such as the 
SDI case, in which copyrighted software located in Bermuda was licensed to the Netherlands and from there licensed to the United States, and royalties were paid from the United States to the Netherlands and from the Netherlands to Bermuda. This was beneficial to the company because the Netherlands has a DTT with the United States that reduces taxation of the royalties to zero and Bermuda (a tax haven) does not. In that case, the IRS argued that although the royalties from the Netherlands to the United States were protected by the DTT, the royalties from the Netherlands to Bermuda were also U.S.-source royalties because of the software's use in the United States; however, the court rejected that argument, saying that if it permitted the taxation of the NetherlandsBermuda royalties it would be allowing double taxation if the U.S.-Netherlands royalties were not protected by DTT. This seems like a strange argument because the treaty-shopping occurred only because of the DTT, so that there would be no U.S.-Netherlands royalties if the DTT did not exist.

Most U.S. DTTs did not have elaborate anti-treaty-shopping mechanisms before the I980s, and other countries were able to use those DTTs to get reduced withholding taxation. Consider the example of the Netherlands Antilles, a Caribbean tax haven that used to belong to the Netherlands. Before the enactment of the portfolio interest exemption in 1984, U.S. companies established Netherlands Antilles subsidiaries and were subject to a zero withholding tax on interest from those subsidiaries through the U.S.-Netherlands DTT. In I984, the United States terminated the extension of the DTT to the Netherlands Antilles and enacted a portfolio interest exemption; at the same time, it instituted a limitation of benefits. These limitation-of-benefits articles in U.S. DTTs are often much more complicated than the model version because other countries want to create loopholes to allow for treaty-shopping. In addition, the OECD and UN models do not contain limitation on benefits, although the commentary on Article I of the OECD model has a model limitation on benefits article.

Limitation-of-benefits provisions state that the DTT confers benefits only on individuals who are physically present in the other DTT country and companies that either are publicly traded on a stock exchange of the other country or are privately owned companies that do not pay half or more of their income to a resident of a nontreaty country. Thus, the U.S. model DTT takes the view that reductions in source income taxation should be accompanied by increases in residence income taxation. For example, the residence article states that if an entity is fiscally transparent in the residence country and is a partnership not subject to residence-based taxation, the entity really belongs to a group of people in another country and is therefore not considered a resident. Thus, the DTT attempts to reduce taxation at the source only if taxation increases on a residence basis, although it is unclear that the limitation-on-benefits provisions really achieve this purpose.

The U.S. model DTT also includes an earning stripping provision that prevents the deduction of too much interest from the United States. Note, however, that the provision applies to interest but not to royalties; companies may therefore 
strip earnings through royalties without penalty. The OECD and UN models do not include this provision.

The United States is probably correct in insisting on limitation of benefits, although other countries certainly do not agree that they need to abide by the U.S. position. Without limitation of benefits, nontreaty countries have less incentive to negotiate because they have a so-called "treaty with the world," meaning that they can always benefit from other countries' DTTs by entering the DTT network through another country.

Article 24 contains a nondiscrimination provision stating that countries may not discriminate against residents of the other country. This provision is weak compared with similar provisions in the GATT and the BITs, and is hard to enforce. Article 25 is the competent authority procedure for mutual agreement, which provides for some (generally nonbinding) arbitration in cases where the DTT lacks binding force. The OECD model now contains a binding arbitration provision designed to prevent double taxation, and some new U.S. DTTs include a similar provision. Note, however, that no DTT provides for binding arbitration at the request of the taxpayer, like the BITs and NAFTA.

The last important component of the model DTT is the exchange-of-information provision, which is found in Article 26. The United States and most other OECD countries believe that this provision is essential if it is to enforce residence-based taxation on its own residents. The United States has been willing to forgo the ratification of a DTT rather than ignore this provision. For example, the U.S.-Israel DTT was delayed for almost twenty years because the Israelis were not willing to give sufficient written assurance of cooperation in exchange-of-information requests. The exchange-of-information provision raises important privacy questions: Is it necessary to make a specific request for specific information about a specific resident, or is it possible to request information about a group of residents without including names? In addition, bank secrecy provisions mean that often a government might not have the information requested. In addition, no worldwide system of tax identification numbers exists, so it is not necessarily true that information provided by a country could be linked to specific taxpayers.

Now we turn to two topics that are important in DTT negotiation, although they are not included in the model DTTs. The first topic is tax sparing, reflected in the provisions of Article 23, which requires that foreign tax credit be given only if foreign taxes are actually paid. A number of countries provide for taxsparing credits; Germany and Japan, for example, give credit for taxes that would have been collected at source from a permanent establishment or a subsidiary except for a tax holiday. The rationale is that a tax holiday in the absence of tax sparing may simply lead to a taxpayer owing more tax to the residence country; however, this may be an overly narrow interpretation because the availability of deferral and averaging (cross-crediting between high and low-tax jurisdictions) mean that tax holidays usually benefit taxpayers even without tax sparing. Tax sparing has been an especially contentious issue in DTT ratification: The U.S. 
Senate has been insistent that it will never ratify a DTT that provides for tax sparing because it can result in double nontaxation.

The second issue involves DTT overrides, which are a mostly U.S. provision with relatively limited scope. The U.S. Congress takes the position that treaties do not have a status above domestic laws; the treaty is superior if it is implemented after a law, but the law is superior if it is implemented after the treaty. Treaty overrides are based on the supremacy clause in the U.S. Constitution that says that laws and treaties shall be the supreme law of the land. Because laws and treaties are used in the same sentence, without a specific priority given to one or the other, the clause has been interpreted to mean that laws and treaties have the same status. Unlike laws, however, treaties are negotiated with another party; the other party may feel that it is entitled to the benefits of the treaty without the risk that the treaty will be unilaterally changed by the U.S. Congress, and international law supports this argument. The U.S. position is based on the argument that DTTs are only ratified by the Senate whereas tax laws have to be passed by both houses of Congress, and therefore Congress must to be able to supersede DTTs.

Although DTT overrides are a contentious issue, the actual number of DTT overrides are relatively small. One explicit DTT override was the branch profit tax provision in I986, which added a limitation-of-benefits rule to preexisting U.S. DTTs that did not have such a provision. This override is generally obsolete now because almost all of the DTTs that it affected have since been renegotiated.

The most recent example of a DTT override occurred in the context of tax arbitrage. This was a situation in which a Canadian company had an U.S. subsidiary with U.S.-source income, which it repatriated to Canada. For U.S. tax purposes, the subsidiary was treated as a branch, and the payments to Canada were treated as interest that was deductible and subject to a reduced withholding tax under the U.S-Canada DTT. For Canadian tax purposes, the U.S. subsidiary was treated as a corporation, and the payments were treated as dividends, which are exempt in Canada. The result was double nontaxation.

The United States took the position that a reduction in tax on source income should be contingent on an increase in tax on residence income. The United States, therefore, passed a DTT override stating that taxation would not be reduced for hybrid entities that are treated inconsistently. Almost immediately, Canada agreed with the interpretation of the DTT and negotiated a protocol to change the DTT. Although this may imply that the DTT override was unnecessary because the Canadians were willing to renegotiate, it takes a lot of time to negotiate a protocol, so it was not necessarily inappropriate for the United States to use a DTT override.

Because of the contention surrounding DTT overrides, the United States hesitates to make use of the provision and has been very careful not to override DTTs since I986. In general, the United States attempts to avoid overrides and the appearance of overrides. When the U.S. earning stripping rule (restricting interest 
deductions to tax-exempt related parties) was enacted in I989, the United States went to great lengths to avoid the appearance of a DTT override by extending the provision to domestic tax-exempt entities and not just to foreigners, thus preventing an apparent violation of the nondiscrimination article.

In general, DTTs between developing countries and developed countries benefit the developing countries despite the absence of tax sparing because DTTs ensure developed country investors a certain level of institutional stability in the developing country. However, empirical economic studies have failed to show that the existence of a DTT materially affects foreign direct investment. This is unsurprising for DTTs between developed countries, which mostly affect the distribution of revenue between the governments of the two countries, but similar studies of DTTs between developing and developed countries also fail to show that the existence of a DTT has a significant positive effect on the flows of foreign direct investment into the developing country. Nevertheless, most scholars believe that DTTs increase investor confidence in the stability of investing in developing countries, and therefore, although the developing country might forgo some tax revenue from the DTT, it probably benefits in the long run from the increased foreign direct investment.

One final important issue regarding DTT's is why they are bilateral, rather than multilateral, such as the GATT. The usual explanation is that DTTs depend too much on the specific investment flows between countries, and therefore cannot be multilateral; however, the fact that developing countries are willing to enter into DTTs even if they lose revenue suggests that this is not a complete explanation. In my view, the fact that DTTs are bilateral is mostly due to the fact that the models were developed before World War II, when bilateral treaties were the norm, and when differences between the tax laws of different countries were larger than they are today. If that is true, it suggests that the time may be at hand to try to negotiate a multilateral DTT, especially given the difficulty DTTs face when dealing with "triangular cases" involving third countries. Tax laws have converged a lot since the I920s, and multilateral treaties are now the norm, so that a renewed effort to negotiate such a multilateral DTT (perhaps in the World Trade Organization context) seems to be called for. 